\title{
Komunikasi Interpersonal Yesus dan Implementasinya Bagi Pelayanan Gereja
}

\author{
Yolantya Widyasari \\ Institut Agama Kristen Negeri Palangka Raya \\ yolantya@stakn-palangkaraya.ac.id
}

\begin{abstract}
Communication is certainly a primary aspect of church ministry. But the reality is that there are often imbalances that result in church divisions due to ineffective communication. The purpose of this paper is to find out how the communication that Jesus did, especially in interpersonal communication techniques and their implementation for church services. Interpersonal communication itself is defined as a state of interaction in face-to-face events. This study uses a literature study approach, namely by reading, taking notes and processing research materials. The description of this topic is from several stories of Jesus' interpersonal communication in the Gospels. The result of the theoretical study is how Jesus always paid attention to the communication component. He shapes the message by adjusting the various characteristics of the communicant and adapting to each context that occurs. Then Jesus is also able to overcome every disturbance well, and produces various extraordinary responses from each recipient of His message, and achieves the goal of effective interpersonal communication. The interpersonal communication that Jesus did can also be implemented in church services, namely pastoral counseling services.
\end{abstract}

Keywords: interpersonal; jesus; service; church

\begin{abstract}
Abstrak
Komunikasi tentu menjadi aspek primer dalam pelayanan gereja. namun kenyataan yang dijumpai, seringkali terjadi ketimpangan yang mengakibatkan perpecahan gereja karena komunikasi yang tidak efektif. Tujuan penulisan ini mencoba menemukan bagaimana komunikasi yang Yesus lakukan, khususnya dalam teknik komunikasi interpersonal dan implementasinya bagi pelayanan gereja. Komunikasi interpersonal sendiri didefinisikan sebagai suatu keadaan interaksi dalam peristiwa tatap muka. Kajian ini menggunakan metode pendekatan studi pustaka, yaitu dengan membaca, mencatat dan mengolah bahan penelitian. Uraian topik ini, yaitu dari beberapa kisah komunikasi interpersonal Yesus dalam kitab-kitab Injil. Hasil kajian teori adalah bagaimana Yesus selalu memperhatikan komponen komunikasi. Ia membentuk pesan dengan menyesuaikan berbagai karakteristik komunikan dan menyesuaikan setiap konteks yang terjadi. Kemudian Yesus juga mampu mengatasi setiap gangguan dengan baik, dan menghasilkan berbagai respon yang luar biasa dari setiap penerima pesan-Nya, serta mencapai tujuan komunikasi interpersonal yang efektif. Komunikasi interpersonal yang Yesus lakukan juga dapat diimplementasikan dalam pelayanan gereja, yaitu salah satunya pelayanan pastoral konseling.
\end{abstract}

Kata kunci: interpersonal; yesus pelayanan; gereja

\section{Pendahuluan}

Pada awal penciptaan dunia, Tuhan membentuk manusia sebagai makhluk sosial yang dilengkapi dengan kemampuan berkomunikasi. Menurut Robbins kemampuan adalah sebagai suatu kapasitas individu untuk mengerjakan berbagai tugas dalam suatu pekerjaan (Suratno, 2013). Selanjutnya, menurut Berelson dan Steiner, komunikasi ialah 
transmisi informasi, gagasan, emosi, keterampilan dan sebagainya, dengan menggunakan simbol-simbol, kata-kata, gambar, figur, grafik, dan sebagainya. Tindakan atau proses transmisi itulah yang disebut komunikasi (Mulyana, 2010:68).

Sebelum manusia jatuh dalam dosa, Adam berkomunikasi secara interpersonal dengan Allah. Komunikasi interpersonal sendiri adalah komunikasi yang terjadi pada dua individu, seperti orang tua dan anak, suami dan istri, dua sahabat dekat, dua sejawat, guru dan murid, dan sebagainya. Melalui komunikasi interpersonal, kita belajar makna cinta, kasih, simpati, hormat, bahkan iri hati serta kebencian (Maulana, 2013). Sejak manusia pertama jatuh dalam dosa, maka komunikasi Allah dengan umat manusia menjadi retak. Sehingga Allah berkomunikasi dengan manusia melalui alam, seperti yang tertulis pada Kitab Mazmur 19:1-6, bagaimana langit menceritakan kemuliaan Allah dan cakrawala memberitakan pekerjaan tangan-Nya. Selain itu, Allah juga berkomunikasi melalui perantaraan nabi-nabi-Nya, karena dosa membuat kemuliaan Allah itu menghanguskan. Salah satunya adalah saat Allah berkomunikasi dengan Musa, malaikat Allah menampakkan diri dalam nyala api. Kemudian pada peristiwa Musa turun dari gunung Sinai membawa dua loh batu yang baru. Itulah sebabnya Allah memilih nabi untuk menjadi perantara-Nya (Hutagalung, 2014).

Berbagai cara Tuhan lakukan sebagai bentuk inisiatif-Nya dalam memperbaiki komunikasi dengan umat manusia. Puncak tertinggi dari komunikasi Allah kepada manusia, yaitu melalui Yesus Sang Putra Allah. Kitab-kitab Injil dalam Perjanjian Baru, yaitu Injil Matius, Injil Markus, Injiil Lukas, dan Injil Yohanes, banyak menulis tentang kehidupan Yesus, serta komunikasi yang dilakukan-Nya. Kata "injil" diterjemahkan dari kata Yunani "euangelion", yang berarti "kabar baik." Jadi, ketika Alkitab berbicara tentang injil, Alkitab sedang berbicara tentang kabar baik tentang Yesus. Masing-masing tulisan dimulai dengan memperkenalkan Yesus sebagai tokoh utama dalam cerita, serta menjelaskan tujuan-Nya untuk membawa keselamatan. Kitab-kitab Injil memberi kesimpulan dengan menjabarkan hasil pelayanan Yesus di bumi, dan memampukan setiap umat-Nya untuk mengikuti teladan Yesus (Ministries, 2012).

Bagi setiap umat Tuhan, komunikasi tentu menjadi aspek primer dalam pelayanan gereja. Namun kenyataan yang dijumpai, seringkali terjadi ketimpangan yang mengakibatkan perpecahan gereja karena komunikasi yang tidak efektif. Tujuan penulisan ini mencoba menemukan bagaimana komunikasi yang Yesus lakukan, khususnya dalam teknik komunikasi interpersonal dan implementasinya bagi pelayanan gereja.

\section{Metode}

Kajian ini menggunakan metode atau pendekatan studi pustaka (library research). Studi pustaka dapat diartikan sebagai serangkaian kegiatan yang terkait dengan metode pengumpulan data pustaka, yaitu membaca, mencatat dan mengolah bahan penelitian (Zed, 2003). Langkah-langkah yang dilakukan dalam kajian ini, yaitu dengan membaca berbagai referensi seperti buku, jurnal, maupun website yang berkaitan pada topik ini. Kemudian penulis mendeskripsikan, serta menguraikan secara komprehensif, setelah itu 
penulis menarik kesimpulan dengan memaparkan dari sudut pandang teori komunikasi, secara khusus komunikasi interpersonal.

\section{Hasil dan Pembahasan}

\section{Komunikasi Interpersonal}

Langkah awal dalam memahami makna dari komunikasi interpersonal, yaitu dengan melacak kata/bahasa dari interpersonal itu sendiri. Kata interpersonal merupakan turunan dari awalan inter, yang berarti "antara," dan kata person, yang berarti pribadi/orang. Jadi, Komunikasi Interpersonal atau Komunikasi Antarpribadi merupakan komunikasi yang berlangsung dalam situasi tatap muka antara dua orang atau lebih, baik secara teorganisasi maupun pada kerumunan orang (Wiryanto, 2004).

Menurut Cangara (2004:4), komunikasi adalah suatu hal yang sangat fundamental dalam kehidupan umat manusia. Manusia memiliki kebutuhan untuk berhubungan dengan sesamanya. Secara lebih rinci, komunikasi interpersonal didefinisikan sebagai suatu keadaan interaksi dalam peristiwa tatap muka. Ketika seorang pembawa pesan atau disebut komunikator, mengirimkan pesan atau stimulus, biasanya berupa simbol-simbol verbal, untuk mengubah tingkah laku orang lain yang menerima pesan.

Menurut Suranto (2011), komponen-komponen komunikasi interpersonal terdiri dari beberapa hal berikut : 1) Sumber/komunikator: merupakan orang yang mempunyai kebutuhan untuk berkomunikasi dan memiliki keinginan untuk membagi keadaan internalnya sendiri; 2) Encoding: merupakan suatu aktivitas internal pada komunikator ketika menciptakan pesan, baik itu melalui pemilihan simbol-simbol dalam bentuk verbal dan non verbal, serta disusun berdasarkan aturan tata bahasa, kemudian disesuaikan dengan karakteristik komunikan; 3) Pesan: merupakan hasil encoding. Pesan adalah seperangkat simbol-simbol, baik verbal maupun non verbal, atau gabungan keduanya, yang mewakili keadaan khusus komunikator untuk disampaikan kepada pihak lain; 4) Saluran: merupakan sarana fisik penyampaian pesan dari komunikator kepada komunikan; 5) Penerima/komunikan: merupakan seseorang yang menerima, memahami, dan menginterpretasi pesan; 6) Decoding: Merupakan kegiatan internal dalam diri penerima; 7) Respon (feedback): Merupakan apa yang telah diputuskan oleh penerima dan menjadi sebuah tanggapan terhadap pesan. Respon atau umpan balik dapat bersifat positif, netral, maupun negatif; 8) Gangguan (noise): merupakan apa saja yang mengganggu atau membuat kacau penyampaian dan penerimaan pesan, termasuk yang bersifat fisik dan psikis; dan 9) Konteks: komunikasi selalu terjadi dalam suatu konteks tertentu, paling tidak ada tiga dimensi, yaitu ruang, waktu, dan nilai. Konteks ruang menunjuk pada lingkungan konkrit dan nyata tempat terjadinya komunikasi, seperti ruangan, halaman, dan jalanan. Konteks waktu menunjuk pada waktu kapan komunikasi tersebut dilaksanakan, seperti pada pagi, siang, sore, malam. Konteks nilai, meliputi nilai sosial dan budaya yang mempengaruhi suasana komunikasi, seperti adat istiadat, situasi rumah, etika, tata krama, dan sebagainya.

Arni Muhammad (2005) menyatakan bahwa Komunikasi Interpersonal mempunyai beberapa tujuan, yaitu: 1) Menemukan diri sendiri. Bila seseorang terlibat 
dalam komunikasi dengan orang lain, mereka akan banyak belajar tentang dirinya sendiri, maupun diri orang lain; 2) Menemukan Dunia Luar. Segala bentuk informasi seringkali didiskusikan, dipelajari, atau bahkan didalami melalui interaksi interpersonal; 3) Membentuk dan menjaga hubungan yang penuh arti dengan orang lain; 4) Mengubah sikap dan tingkah laku; 5) Untuk mencari kesenangan; dan 6) Untuk membantu ahli-ahli kejiwaan, ahli psikologi klinis dan terapi. Mereka mengarahkan kliennya dengan menggunakan komunikasi interpersonal dalam kegiatan profesional mereka.

Sehingga dapat disimpulkan bahwa komunikasi interpersonal merupakan suatu proses pertukaran makna antara orang-orang yang saling berkomunikasi. Orang yang saling berkomunikasi tersebut adalah komunikator dan komunikan. Komunikator melakukan encoding untuk menciptakan dan memformulasikan pesan menggunakan saluran dengan menyesuaikan konteks tertentu. Hambatan dapat terjadi pada komunikator, encoding, pesan, saluran, decoding, maupun pada diri komunikan. Ketika melakukan komunikasi interpersonal, setiap individu dapat mempunyai tujuan yang berbeda-beda, sesuai dengan kebutuhan masing-masing.

\section{Pelayanan Gereja}

Gereja adalah kumpulan jemaat pilihan, yaitu mereka yang dipanggil oleh Allah untuk keluar dari dunia dan pergi dari dosa, serta masuk ke dalam wilayah anugerah. (Sproul, 2002). Kata Perjanjian Baru untuk gereja adalah ékklesiatikal yang artinya mereka yang dipanggil keluar (Purwoto, 2020). Menurut Widyatmadja (2009) panggilan gereja atau biasa dikenal dengan Tri tugas gereja yaitu Koinonia (Persekutuan), Marturia (Kesaksian), dan Diakonia (Pelayanan). Gereja yang seutuhnya adalah seutuhnya dalam melakukan panggilan gereja (Siswanto, 2016).

Misi Gereja adalah mewartakan Firman Allah untuk mewujudkan kerajaan Allah di dunia. Misi tersebut tidak akan dapat dilakukan tanpa diakonia atau pelayanan sebab diakonia adalah fungsi Gereja yang sebenarnya (Sitanggang, 2004). Pelayanan tersebut bukanlah suatu pilihan atau kekhususan bagi para pelayan tahbisan akan tetapi merupakan tugas dan tanggung jawab bagi setiap orang yang telah menerima baptisan. (Siswanto, 2016). Selama hidup di dunia, Yesus selalu mengadakan persekutuan, menyampaikan kesaksian, dan melakukan pelayanan. Sebagai Pelayan berarti tidak memerintah tetapi melayani, karena di dalam gereja tidak ada istilah pendetakrasi, penatuakrasi atau majeliskrasi melainkan kristokrasi (Tangiruru, 2020).

\section{Komunikasi Interpersonal Yesus}

Berdasarkan penelitian terdahulu yang dilakukan oleh Purba (2019), yang meneliti tentang kreatifitas Yesus dalam membangun hubungan Interpersonal dengan murid-murid-Nya dan implementasinya bagi dosen Pendidikan Agama Kristen. Maka, berbeda dari penelitian sebelumnya, pada penelitian ini peneliti memfokuskan kajian Komunikasi Interpersonal yang dilakukan oleh Yesus dengan tujuan untuk menemukan implementasinya bagi pelayanan gereja. 
Kedatangan Yesus ke dunia merupakan bentuk komunikasi Allah dengan manusia. Allah mempunyai pesan/firman yang harus disampaikan kepada umat manusia. Seperti firman Tuhan dalam Injil Yohanes 14:6 tertulis demikian, "Kata Yesus kepadanya, Akulah jalan dan kebenaran dan hidup. Tidak ada seorang pun yang datang kepada Bapa kalau tidak melalui Aku." Jadi, bagi umat Kristen, Yesus adalah jalan relasi dan komunikasi Allah dengan manusia, dan manusia dengan Allah. Yesus merupakan satu-satunya mediator dan komunikator yang Agung, hanya Dia yang memenuhi syarat untuk mengkomunikasikan Allah yang Maha Kudus kepada manusia yang berdosa. (Christanday, 2015).

Setiap penulis Kitab-kitab Injil adalah saksi mata kehidupan Yesus atau orang yang memiliki kontak langsung dengan kehidupan Yesus. Seperti Matius dan Yohanes, mereka adalah murid-murid Yesus, mereka hadir dalam banyak peristiwa yang mereka catat. Markus adalah orang yang dekat dengan Petrus, dan belajar secara langsung dari Petrus. Dan Lukas melakukan perjalanan bersama Paulus, serta mencari para saksi mata yang dapat diandalkan untuk Injilnya (Ministries, 2012).

Yesus berkomunikasi dimana saja, mencakup berbagai wilayah seperti rumah ibadah, rumah pribadi, tempat umum, laut, bukit, dan lain-lain. Ia selalu menyesuaikan konteks ruang, waktu, dan nilai dalam berkomunikasi. Seringkali Ia berkomunikasi pada kerumunan orang, bahkan juga beberapa kali berkomunikasi secara interpersonal. Pesan yang disampaikan-Nya selalu mengambil cerita dari kehidupan sehari-hari, seperti pekerjaan gembala, nelayan, penabur, serta perumpamaan lainnya. Dan itu baru sebagian dari cara Tuhan kita berkomunikasi (Buyung, 1992).

Dalam kaitannya dengan teori komunikasi Interpersonal, Yesus sebagai seorang komunikator, menciptakan pesan, kemudian menyesuaikannya dengan karakteristik komunikan. Seperti ketika Yesus sedang berkhotbah di bukit, Ia menggunakan bahasa yang sederhana. Namun, ketika sedang berbicara dengan seseorang yang terpelajar, Yesus menggunakan bahasa filosofis. Contohnya saat Yesus bercakap-cakap dengan Nikodemus yang tertulis dalam Yohanes 3:1-17. Nikodemus adalah seorang Farisi, pemimpin orang-orang Yahudi atau Sanhedrin, dan juga Ahli Taurat. Jadi, dapat dikatakan bahwa Nikodemus adalah orang yang berkedudukan sangat tinggi, religius, dan terdidik. Dalam proses komunikasi interpersonal Yesus kepada Nikodemus, terlihat bagaimana Yesus selalu mengacu pada kebutuhan sang komunikan. Yesus tidak menunjukkan minat untuk berkomunikasi atau bahkan berdebat tentang hal-hal yang tidak menyentuh hati atau dosa. Yesus langsung pada inti pesan yang dibutuhkan komunikan, sehingga Yesus mampu memenangkan hati orang yang menerima pesan-Nya.

Salah satu kisah lainnya yang tertulis dalam kitab Injil, yaitu tentang komunikasi interpersonal Yesus dengan seorang Perempuan Samaria, yang tertulis dalam Yohanes 4:4-26. Percakapan tersebut terjadi di pinggir sumur Yakub. Konteks waktu saat itu pada tengah hari, kira-kira pukul dua belas. Kemudian jika melihat konteks nilai yang terjadi pada zaman itu, jarang sekali bagi orang-orang Yahudi berkomunikasi dengan orang Samaria, "sebab orang Yahudi tidak bergaul dengan orang Samaria" (Ayat 9). Tetapi 
dalam proses Komunikasi Interpersonal-Nya, Yesus memulai dengan apa yang dirasakan oleh perempuan Samaria itu. "Berilah Aku minum" merupakan perkataan awal Yesus ketika menyapanya. Pesan dalam kalimat tersebut tidak sekedar menyatakan bahwa Yesus membutuhkan air minum, tetapi perkataan itu juga bisa bermakna, bahwa Yesus ingin bersahabat dengan perempuan Samaria itu. Percakapan Yesus dengan Perempuan Samaria langsung menyentuh ebutuhannya. Pesan yang Yesus sampaikan itu, tentu memberikan respon yang positif, bahkan mampu mengubah tingkah laku Perempuan Samaria.

Begitu pula dengan kisah lainnya, ketika Yesus berkomunikasi dengan Zakheus ang pemungut cukai (Lukas 19:1-10). Dalam komponen komunikasi interpersonal, Zakheus emiliki gangguan atau noise dari fisiknya yang tidak terlalu tinggi untuk dapat melihat Yesus, namun dapat teratasi saat ia berusaha menaiki pohon. Walaupun banyak orang yang membenci Zakheus, namun Yesus menyambutnya dengan pesan verbal yang menghibur, bahkan juga pesan non verbal, yaitu dalam bahasa tubuh yang bersahabat. Sehingga perjumpaannya dengan Yesus telah mendatangkan sukacita dalam dirinya, serta mendorong Zakheus untuk memperbaiki hidupnya.

Kemampuan Yesus dalam mengajar atau berkomunikasi membuat banyak orang takjub. Orang-orang melihat-Nya sebagai sosok yang istimewa, beda dari pemimpin agama pada umumnya. (Lilo, 2019). Kitab Injil mencatat bahwa setiap perkataan yang Yesus sampaikan, selalu meninggalkan kesan yang menakjubkan bagi setiap pendengarNya. Dalam Matius 7:28 berbunyi "Dan setelah Yesus mengakhiri perkataan ini, takjublah orang banyak itu mendengar pengajaran-Nya." Kemudian dalam Markus 1:22 juga berkata "Mereka takjub mendengar pengajaran-Nya, sebab Ia mengajar mereka sebagai orang yang berkuasa, tidak seperti ahli-ahli Taurat." Begitu pula dalam Lukas 4:32 tertulis "Mereka takjub mendengar pengajaran-Nya, sebab perkataan-Nya penuh kuasa."

Yesus sebagai seorang komunikator yang handal, selalu memulai komunikasinya dari pemahaman akan manusia yang dihadapi-Nya. Ia menyampaikan pesan selalu berorientasi kepada kebutuhan sang komunikan. Komunikasi dikatakan efektif, bila pihak lain atau komunikan, mengerti maksud komunikator dan bertindak sesuai dengan keinginan komunikator. Di sisi lain, untuk menciptakan suatu persahabatan, Yesus mengajarkan sikap adaptif dalam berkomunikasi. Ia berkomunikasi dengan manusia dalam cara manusia, dan menciptakan suasana persahabatan, serta membentuk hubungan yang penuh arti dengan orang lain.

\section{Implementasi bagi Pelayanan Gereja}

Dalam pelayanan gereja, komunikasi interpersonal dapat diimplementasikan salah satunya dalam Pelayanan Pastoral Konseling. Pastoral berasal dari kata pastor dalam bahasa Yunani disebut poimen yang berarti Gembala (Beek, 2003). Sedangkan konseling dalam bahasa Yunani disebut Parakletos yang diterjemahkan dalam bahasa Indonesia yang berarti penghibur, penasehat dan penolong (Ginting, 2002). Dalam arti lebih sempit, pelayanan gereja pada bidang pastoral konseling adalah dimensi komunikasi dari semua pelayanan gerejawi. Tanpa pemahaman komunikasi interpersonal yang benar, tidak 
mungkin seorang konselor dapat memberi respon dan keputusan yang tepat bagi konsilinya. Begitu pula dengan seorang pelayan gereja, ketika ia sudah mengetahui cara berkomunikasi yang efektif, khususnya secara interpersonal, maka ia akan sanggup menyampaikan informasi dengan cara yang tepat, seperti kemampuan menganalisa, penggunaan kata, kontak mata, intonasi, artikulasi, dan etika yang benar (Saragih, 2009).

\section{Implikasi}

Implikasi teoritis dari tulisan ini dapat dijadikan topik untuk diajarkan dalam kelas-kelas yang berkaitan dengan komunikasi, misi Kristen maupun pastoral konseling, baik di sekolah maupun perguruan tinggi. Terlebih juga dalam praksisnya, sebagai implementasi bagi para gembala maupun umat-umat Tuhan dalam pelayanan gereja dan masyarakat.

\section{Rekomendasi untuk Penelitian Lanjutan}

Topik kajian ini masih lebih banyak membahas dari sudut pandang teori komunikasi. Peneliti memberikan rekomendasi untuk penelitian selanjutnya, dimana perlu untuk menggali lebih dalam bagaimana komunikasi yang dilakukan oleh Yesus selama hidup-Nya di dalam dunia. Kemudian dapat dielaborasikan dengan sudut pandang Teologi, Misiologi, maupun Sosiologi Agama.

\section{Kesimpulan}

Seluruh kitab, baik Perjanjian Lama dan Perjanjian Baru merupakan bentuk Komunikasi Allah dengan manusia. Dan puncak tertinggi dari komunikasi Allah kepada manusia, yaitu melalui Yesus Sang Putra Allah. Kitab Injil banyak menulis tentang kehidupan Yesus dan komunikasi Interpersonal yang dilakukan oleh Yesus. Dimana, komunikasi interpersonal merupakan komunikasi yang terjadi antara komunikator dan komunikan. Yesus sebagai komunikator selalu memperhatikan komponen komunikasi, yaitu membentuk pesan dengan menyesuaikan karakteristik komunikan, menyesuaikan setiap konteks yang terjadi, dan mengatasi setiap gangguan dengan baik, terlebih menghasilkan berbagai respon yang luar biasa dari setiap penerima pesan-Nya, serta mencapai tujuan komunikasi interpersonal yang efektif. Dari apa yang telah Yesus lakukan dalam praktik komunikasi secara interpersonal dengan orang lain, dapat memberikan teladan bagi umat-umat-Nya, secara khusus dalam implementasi bagi pelayanan gereja, baik pelayanan pastoral konseling maupun pelayanan lainnya.

\section{Rujukan}

Alkitab. Jakarta : Lembaga Alkitab Indonesia. 1996.

Arni, Muhammad. (2005). Komunikasi Organisasi. Jakarta: Bumi Aksara.

Beek, Van, Art. (2003). Pendamping Pastoral. Jakarta: BPK Gunung Mulia

Buyung, Yopie F.M. (1992). Komunikasi yang Efektif Dalam Pelayanan. Bandung: Yayasan Kalam Hidup. 
Cangara, Hafied. (2009). Pengantar Ilmu Komunikasi Edisi Revisi. Jakarta: PT. Raja Grafindo Persada.

Cangara, Hafied. (2004). Pengantar Ilmu Komunikasi. Jakarta: PT Raja Grafindo Persada. Christanday, Andreas. (2015). Komunikasi Dalam Keluarga Kristen. Yogyakarta: Yayasan ANDI.

Ginting, E.P. (2002). Gembala dan Pastoral Konseling. Yogyakarta: Yayasan ANDI.

Hutagalung, Stimson. (2014). Firman Tuhan : Pelita dan Pedang Bermata Dua. Jurnal Koinonia, 8(2).

Mulyana, Deddy. (2010). Ilmu Komunikasi Suatu Pengantar. Bandung: PT Remaja Rosdakarya

Maulana, H. Gumelar. G. (2013). Psikologis Komunikasi dan Persuasi. Jakarta: Akademia Permata.

Ministries, Thrid Millennium. (2012). Kitab-kitab Injil, Pelajaran Satu, Pengantar Untuk Kitab-Kitab Injil. Florida: Thrid Millennium Ministries, Inc.

Purba, A. (2019). Kreatifitas Yesus Dalam Membangun Hubungan Interpersonal Dengan Murid-Muridnya Dan Implementasinya Bagi Dosen Pendidikan Agama Kristen. Jurnal TEDC.

Purwoto, P. (2020). Landasan Teologis Pendidikan Kristen dalam Perjanjian Baru dan Relevansinya bagi Pendidikan Kristen Masa Kini. Jurnal DIDAKTIKOS: Jurnal Pendidikan Agama Kristen.

Saragih, Jahenos. (2009). Berteologi Melalui Komunikasi Suatu Refleksi Teologis Kristiani (Jakarta: Suara Gereja Kristen Yang Esa Peduli Bangsa.

Sitanggang, S. (2004). Membangun Gereja Yang Diakonal. P. Siantar: HKBP.

Siswanto, Krido. (2016). Tinjauan Teoritis dan Teologis Terhadap Diakonia Transformatif Gereja. Jurnal Simpson: Jurnal Teologi dan Pendidikan Agama Kristen.

Sproul, R.C. (2002). Kebenaran-Kebenaran Dasar Iman Kristen. Cetakan Ke. Malang: Departemen Literatur SAAT.

Suratno. (2013). Konsep Kemampuan Sumber Daya Manusia. Jurnal Kemenag Kab. Kepl. Sitaro.

Suranto, AW. (2011). Komunikasi Interpersonal. Yogyakarta: Graha Ilmu.

Tangiruru, Veronica. (2020). Peran Gereja Dalam Tugasnya Sebagai Pelayan Allah Dalam Perkembangan Karakter Kristiani Pemuda. Osf.io.

Wiryanto. (2004). Pengantar Ilmu Komunikasi. Jakarta: PT. Gramedia Widasarana Indonesia

Zed, Mestika. (2003). Metode Penelitian Kepustakaan. Jakarta: Yayasan Obor Indonesia. 